\title{
DESAIN PENGEMBANGAN KURIKULUM BAHASA ARAB: PENDEKATAN OTAK KANAN
}

\author{
Muhammad Yusuf \\ Universitas Islam Negeri Sunan Kalijaga Yogyakarta \\ elyusuf03@gmail.com
}

\begin{abstract}
This paper aims to discuss the development of the Arabic language curriculum based on the right brain approach. This paper relies on bibliographic sources in the form of books and articles (literature studies) which are in the scientific journal related to the subject matter. Reading the data of thought by academics using a critical constructive approach and meaning of the substance with content analysis. Based on the studies that have been conducted, the right brain approach in learning Arabic can be narrated as an axiomatic way of thinking about how to learn Arabic by optimizing right brain functions which include rhymes, rhythms, music, visual impressions, colors, and images. Thus the purpose of learning Arabic is the students are able to obtain Arabic language knowledge that is ready to be used in the field of scientific and practical social in the community, in a way that is fun and full of enthusiasm. The method that can be used is the psychological method. While in learning techniques in principle, it must be able to attract students' interests and motivations, encourage students to think critically-creatively-holistically, and must encourage students to be cooperative and interactive.
\end{abstract}

Keywords: curriculum development, Arabic, right brain

Abstrak: Tulisan ini bertujuan untuk mendiskusikan pengembangan kurikulum bahasa Arab dengan berbasis pada pendekatan otak kanan. Tulisan ini mengandalkan sumber bibliografis berupa buku dan artikel (studi pustaka) yang berada dijurnal ilmiah yang berkaitan dengan pokok permasalahan. Pembacaan data pemikiran para akademisi dengan menggunakan pendekatan konstruktif kritis dan pemaknaan substansinya dengan analisis isi. Berdasarkan kajian yang telah dilakukan, pendekatan otak kanan dalam pembelajaran bahasa Arab bisa dinarasikan sebagai cara berfikir aksiomatis tentang cara belajar bahasa Arab dengan mengoptimalkan fungsi otak kanan yang meliputi rima, irama, musik, kesan visual, warna, dan gambar. Dengan demikian tujuan pembelajaran bahasa Arab adalah agar siswa mampu memperoleh ilmu kebahasa Araban yang siap digunakan dalam lapangan keilmuan dan praktis sosial dimasyarakat, dengan cara yang menyenangkan dan penuh dengan semangat. Adapun metode yang bisa digunakan adalah psychological method. Sementara dalam tekhnik pembelajaran pada prinsipnya 
harus dapat menarik minat dan motivasi siswa, mendorong siswa berfikir kritis-kreatif-holistik, dan harus mendorong siswa untuk kooperatif dan interaktif.

Kata-kata kunci: pengembangan kurikulum, bahasa Arab, otak kanan

\section{A. Pendahuluan}

Salah satu prioritas pembangunan nasional di bidang pendidikan dalam rangka pengembangan kualitas sumber daya manusia adalah peningkatan mutu setiap jenis dan jenjang pendidikan. Oleh karena itu, pemerintah selalu berupaya memberikan atensi yang signifikan terhadap kualitas sumber-sumber pendidikan dalam rangka menunjang pendidikan, salah satunya adalah kurikulum pembelajaran. ${ }^{1}$

Kurikulum $^{2}$ merupakan desain atau blue print bagi pendidikan khususnya dalam proses kegiatan pengajaran. Kurikulum adalah a plan for learning atau pengalaman yang direncanakan dalam kegiatan belajar mengajar bagi peserta didik. Oleh karena itu, tidak berlebihan bila dikatakan bahwa kualitas kurikulum bisa dijadikan tolak ukur kualitas hasil belajar peserta didik. Dengan demikian, agar peran dan fungsi kurikulum dapat optimal, diperlukan pengembangan yang mampu memformulasikan semua tindakan upaya perbaikan penataan kurikulum tersebut dalam suasana dinamis demokratis, ${ }^{3}$ dan juga humanis. ${ }^{4}$ Acuan yang dimuat harus bersifat fleksibel, terbuka, serta merangsang dinamika siswa secara optimal. Upaya peninjauan terhadap keabsahan kurikulum yang mempunyai posisi strategis bagi pendidikan merupakan sebuah keniscayaan. Sifat korektif yang dinamis ini perlu berjalan simultan sesuai dengan perkembangan zaman dan kebutuhan masyarakat.

1 Mohammad Asrori, Pengembagan Kurikulum Bahasa Arab Di Pesantren (Malang: UINMaliki Press, 2013),. 1.

2 Secara etimologi kurikulum berasal dari bahasa Yunani, yaitu curir yang berarti berlari dan curere yang berarti tempat berpacu. Dengan demikian, istilah kurikulum berasal dari dunia olahraga pada zaman Romawi kuno di Yunani, yang mengandung pengertian jarak yang harus ditempuh oleh pelari dari garis start sampai finish. Adapun secara terminologi kurikulum dapat diartikan sebagai seperangkat materi pendidikan dan pengajaran yang diberikan kepada murid sesuai dengan tujuan pendidikan yang akan dicapai. Adapun dalam konteks pendidikan Islam, kurikulum merupakan suatu jalan terang yang dilalui pendidik terhadap anak didik untuk mengembangkan pengetahuan, keterampilan, dan sikap mereka. Lihat dalam Abdullah Idi, Pengembangan Kurikulum "Teori dan Praktik” (Jogjakarta: Arruzz Media, 2013), 206.

3 Demokratisasi dalam konteks pendidikan dapat diartikan sebagai pembebasan pendidikan dan manusia dari struktur dan sistem perundangan yang menempatkan manusia sebagai komponen. Menurut Hujair Sanaky, demokratisasi pendidikan merupakan pendidikan hati nurani. Artinya, pendidikan yang lebih menghargai potensi manusia, lebih humanis, beradab, dan sesuai dengan citacitta masyarakat madani. Melalui demokratisasi pendidikan, diharapkan akan terjadi proses kesataran antara pendidik dan peserta didik dalam proses belajar-mengajar. Lihat Dalam Haryanto al-Fandi, Desain Pembelajaran Yang Demokratis dan Humanis (Jogjakarta: Arruz Media, 2011), 167.

4 Suasana humanis dalam pandangan Abdurahman Mas'ud merupakan suasana pendidikan yang lebih memperhatikan aspek potensi manusia sebagai mankhluk sosial (berkemanusiaan, makhluk religius (beketuhanan), serta individu yang diberi kesempatan oleh Allah untuk mengembangkan potensinya. Ibid, . 189. 
Dalam konteks kekinian, dominasi aspek hafalan dalam muatan kurikulum menjadi salah satu penyebab kegagalan pendidikan dalam memainkan peranannya sebagai motor lahirnya peradaban manusia yang lebih tinggi. ${ }^{5}$

Dalam konteks bahasa Arab, di Indonesia ia dipelajari tidak hanya sebagai bahasa agama tetapi juga bahasa pengetahuan, serta diajarkan dalam usaha memahami atau menafsirkan ayat-ayat al-Qur'an, hadits, dan teks-teks Arab. Meskipun bahasa Arab telah berkembang dan diajarkan cukup lama di Indonesia, namun tampaknya pembelajaran bahasa Arab sampai sekarang tidak luput dari masalah. Dalam dataran realitas, pendidikan bahasa Arab masih menampakkan kesenjangan antara fenomena kehidupan dengan prinsip-prinsip yang diajarkan. Seperti yang dipraktikkan saat ini, isi dan materi pembelajaran bahasa Arab lebih bersifat ideologis dan doktrinal serta tidak peduli terhadap problem kemanusiaan. Hilangnya humanisme berakibat pada kaburnya identitas siswa dan mata pelajaran ini. Disamping itu, orientasi pembelajaran bahasa Arab sampai saat ini lebih banyak dihiasi budaya tekhnikal dan ritualistik yang miskin implikasi: miskin dalam nilai-nilai sosial, moral, spiritual, dan intelektual yang berpihak pada kemanusiaan. Praktik pendidikan bahasa Arab lebih terlihat sebagai pengulang-ulangan materi, mempelajari sesuatu yang sudah baku dan dibakukan, bahkan sekedar memahami sisi lahir teks: aturan, gramatika, tanpa berdasar pada konteks apapun. Bisa dikatakan bahwa rendahnya kemampuan berbahasa siswa karena ketiadaan integrasi dan interkoneksi dalam mata pelajaran bahasa Arab, sehingga mengakibatkan mata pelajaran ini kosong, dan menjauhi dunia otentik. ${ }^{6}$

Dalam kaitan tersebut, agaknya diperlukan revitalisasi dan atau rekonstruksi kurikulum pembelajaran bahasa Arab. Konsekuensi logis dari hal tersebut salah satunya adalah radikalisasi untuk membongkar dan menata kembali basis pembelajaran bahasa Arab, yang sampai sejauh ini di dominasi oleh kerja otak kiri. ${ }^{7}$ Dominasi otak kiri inilah yang pada akhirnya membuat hasil lulusan bahasa Arab secara umum jauh dari dunia otentik dan kurang sensitif dengan problem rill yang ada dimasyarakat. Oleh karenanya, agaknya diperlukan perubahan paradigma dengan menjadikan otak kanan sebagai basis dalam kurikulum pembelajaran. Hal itu dikarenakan secara fungsional otak kanan bekerja pada wilayah emosional dan sosial. ${ }^{8}$ Maka tidak berlebihan bila diasumsikan basis otak kanan dalam pembelajaran

5 Mohammad Asrori, Pengembagan Kurikulum Bahasa Arab Di Pesantren, . 2-3.

.Ibid, .viii-ix

7 Linguistik dan matematika menjadi simbol dari kecerdasan IQ (otak kiri). Lihat Dalam Agus Nggermanto, Quantum Quotient "Kecerdasan Quantum" (Bandung: Nuansa, 2008), 49. Hal tersebut agaknya dikarenakan keduanya dipahami sebagai ilmu pengetahuan kognitif (IQ). Dalam kenyataannya ilmu pengetahuan kognitif sebenarnya hanya merupakan ilmu pengetahuan tentang sebagian pikiran, yaitu bagian yang berkaitan dengan penalaran, pemikiran, dan intelek. Ilmu pengetahuan kognitif mengesampingkan emosi. Lihat Dalam Joseph Ledoux, The Emotional Brain "Penopang Misterius Bagi Kehidupan Emosional" (Yogyakarta: Pustaka Baca, 2011), 22.

8 Douglas Brown, Prinsip Pembelajaran dan Pengajaran Bahasa (Jakarta: Dubes Amerika Serikat, 2008), 63. 
bahasa Arab akan dapat berkontribusi dalam menjawab problem dehumanisasi yang sedang melanda Indonesia, bahkan dunia pada abad 21 ini. $^{9}$

\section{B. Landasan Teori}

\section{Pengembangan Kurikulum Bahasa Arab}

Dalam kurikulum ${ }^{10}$ nasional, semua program belajar sudah baku dan siap untuk digunakan oleh pendidik. Kurikulum yang demikian sering bersifat resmi dan dikenal dengan nama ideal curriculum atau kurikulum yang masih berbentuk cita-cita. Kurikulum yang masih berbentuk cita-cita ini masih perlu dikembangkan menjadi kurikulum yang berbentuk pelaksanaan (actual curriculum), yaitu kurikulum yang dilaksanakan oleh pendidik dalam proses belajar mengajar. ${ }^{11}$ Sementara itu, menurut Muhajir pengembangan kurikulum merupakan suatu keniscayaan, sesuai dengan perkembangan ilmu pengetahuan dan tekhnologi, tuntutan sosial di masyarakat, perkembangan global, dan dilakukan secara priodik. Rekonstruksi kurikulum bahasa Arab adalah sebagai upaya pembekalan basic akademik serta untuk pengembangan pendidikan karakter bangsa (nation character building). ${ }^{12}$

Penyusunan kurikulum mempunyai signifikansi yang tinggi dengan asas organisatoris, yaitu bentuk penyajian bahan pelajaran atau organisasi kurikulum. ${ }^{13}$ Salah satu pola pengorganisasian kurikulum disebut dengan pola integrated curiculum (kurikulum terpadu). Kurikulum terpadu merupakan suatu produk dari usaha pengintegrasian bahan pelajaran dari berbagai macam pelajaran. Integrasi diciptakan dengan memusatkan pelajaran pada masalah tertentu yang memerlukan solusinya dengan materi atau bahan dari berbagai disiplin atau mata pelajaran. ${ }^{14}$

9 Asumsi ini berdasarkan pendapat dari Goleman yang mengatakan bahwa otak kiri (IQ) menentukan kesuksesan seseorang sebesar 20\% sedangkan kecerdasan emosi (EQ) memberi kontribusi 80. Lihat dalam Agus Nggermanto, Quantum Quotient "Kecerdasan Quantum" (Bandung: Nuansa, 2008), 97.

10 Dalam tradisi Arab, padanan istilah kurikulum adalah manhaj derivasi dari kata nahj yang memiliki arti jalan yang sangat jelas. Secara etimologis istilah manhaj bermakna media tertentu untuk mencapai tujuan tertentu pula. Sedangkan secara terminologis manhaj berarti langkah-langkah yang komprehensif yang dipakai oleh seorang guru berdasarkan eksperimen dan dipakai untuk mencapai tujuan yang telah ditetapkan. Perdebatan mengenai definisi kurikulum telah melahirkan dua madzhab, yaitu madzhab traditional dan madzhab modern. Madzhab traditional mendefinisikan kurikulum sebagai sebuah kumpulan pengetahuan mulai dari tujuan, konsepsi, aturan dan teori, yang dipakai oleh guru untuk mengantarkan peserta didiknya menghadapi kehidupan. Sedangkan menurut madzhab modern, kurikulum adalah sekumpulan hasil pengalaman pengajaran yang dijadikan landasan oleh guru untuk mengajar siswanya agar siswa tumbuh secara optimal, baik dari segi nalar, raga, agama, sosial dan budaya serta mencapai tujuan yang telah ditetapkan. Muhammad Najib dalam Muhajir, Arah Baru Arah Baru Pengajaran Bahasa Arab "Filsafat Bahasa, Metode dan Pengembangan Kurikulum” (Yokyakarta: FITK-UIN Sunan Kalijaga, 2017), 167-168.

11 Abdullah Idi, Pengembangan Kurikulum "Teori dan Praktik", . 163.

12 Muhajir, Arah Baru Pengajaran Bahasa Arab "Filsafat Bahasa, Metode dan Pengembangan Kurikulum (Yokyakarta: FITK-UIN Sunan Kalijaga, 2017), 167-168.

13 Ibid

14 Abdullah Idi, Pengembangan Kurikulum "Teori dan Praktik", . 169. 
Kurikulum jenis ini membuka kesempatan yang lebih banyak untuk melakukan kerja kelompok, masyarakat, dan lingkungan sebagai sumber belajar, mementingkan perbedaanindividualanakdidik, dan dalamperencanaan pelajaransiswa diikutsertakan. Kurikulum terpadu sangat mengutamakan agar anak didik dapat memiliki sejumlah pengetahuan secara fungsiona ${ }^{15}$ dan mengutamakan proses belajarnya. ${ }^{16}$

Integrated curriculum mempunyai ciri yang sangat fleksibel dan tidak menghendaki hasil belajar yang sama dari semua anak didik. Guru, orang tua, dan anak didik merupakan komponen-komponen yang bertanggung jawab dalam proses pengembangannya. Kurikulum terpadu juga mementingkan aspek-aspek psikologi yang berpengaruh terhadap integrasi pribadi individu dan lingkungannya. Kurikulum terpadu, menurut Soetopo \& Soemanto dapat dibedakan menjadi beberapa bentuk, yaitu: 1) the child centered curriculum. Maksudnya, dalam perencanaan kurikulum, faktor anak menjadi perhatian utama. 2) the social function curriculum. Maksudnya, kurikulum ini mencoba mengeleminaasi mata pelajaran sekolah dari keterpisahannya dengan fungsi-fungsi utama kehidupan sosial yang menjadi dasar pengorganisasian pengalaman belajar. 3) the experience curriculum. Maksudnya, dalam perencanaan kurikulum, kebutuhan anak merupakan perhatian utama. Kurikulum pengalaman akan terjadi jika hanya mempertimbangkan keberadaan anak didik dengan menggunakan pendekatan social function. 4) development activity curriculum. Kurikulum pengembangan kegiatan sangat tergantung pada tingkat perkembangan anak yang harus dilalui. Deretan perbedaan tiap individu anak didik mesti menjadi dasar pertimbangan, tentang kebutuhan, kebiasaan, dan masalah-masalah yang dihadapi siswa berkaitan dengan kebudayaan dan lingkungan.

Dalam melaksanakan kurikulum terpadu, disusunlah unit sumber yang mencakup bahan, kegiatan belajar, dan sumber-sumber yang sangat luas. Sumber unit digunakan sebagai sumber untuk satuan pelajaran merupakan apa yang secara aktual dipelajari anak didik di kelas. Perbedaan anak didik tidak harus selalu mempelajari halhal yang sama, dan ada kebebasan bagi anak didik untuk memilih pelajaran menurut minat, bakat dan kemampuan mereka masing-masing. Pemahamannya bahwa unit sumber merupakan apa yang secara ideal dapat dipelajari anak didik, sedangkan satuan pelajaran merupakan apa yang secara aktual dipelajari anak didik. ${ }^{17}$

Maksudnya adalah karena ilmu tersebut dikelompokkan berhubungan dengan 10 usaha memecahkan masalah yang ada. Ibid, . 170. Sebagai contoh, dengan belajar bahasa Arab, anak didik seharusnya juga mempelajari ilmu sosial. Karena biar bagaimanapun bahasa Arab identik dengan bahasa Agama Islam yang sangat mementingkan kesalehan .sosial siswa

16 Ibid, . 169-170.

17 Abdullah Idi, Pengembangan Kurikulum "Teori dan Praktik", . 17o 


\section{Diskursus Otak Kanan}

Secara psikologis, hakikat pendidikan adalah optimalisasi seluruh potensi manusia. Seluruh potensi manusia bertumpu pada otaknya. ${ }^{18}$ Oleh karena itu, seharusnya pendidikan terintegrasi dengan ilmu otak (neurosains). ${ }^{19}$ Dalam konteks Indonesia, sistem pendidikan masih mengacuhkan peran ilmu ini. Implikasinya adalah pendidikan cenderung doktrinal-pedagogis bukan rasional-empiris. Hal ini dapat diamati pada pembelajaran konvensional yang memposisikan hubungan guru dan murid demikian: guru mengajar murid diajar, guru tahu murid diberi tahu, guru subjek murid objek, dan seterusnya. ${ }^{20}$

Otak manusia beroperasi secara simultan pada banyak tingkat kesadaran, memproses semua hal seperti dunia warna, gerakan, emosi, bentuk, bau, bunyi, rasa, perasaan, dan banyak lagi secara bersamaan. Otak menggabungkan pola, mengubah makna, dan menyeleksi pengalaman hidup sehari-hari dari berbagai petunjuk. Selain itu, otak juga memproses informasi dengan sangat efisien sehingga tidak ada satupun dalam kehidupan manusia yang dapat menyamai potensi belajar manusia. Banyak para pendidik yang tidak mengetahui bahwa mereka telah menghalangi kemampuan belajar otak dengan mengajar menggunakan gaya yang intralinear, terstruktur, dan terprediksi. Hasilnya adalah membosankan atau membuat frustasi para pembelajar yang kemudian terus berada dalam siklus yang tidak berkembang. ${ }^{21}$ Dalam kaitan tersebut, dapat dikatakan bahwa terdapat korelasi yang erat antara pembelajaran dan cara kerja otak. Semakin luas dan mendalam pendidik memahami cara kerja otak, semakin mudah ia menumbuh kembangkan seluruh potensi peserta didik, dan sebaliknya. $^{22}$

Secara filosofis, hakikat pendidikan adalah membentuk manusia sempurna atau insan kamil. Dalam perspektif psikologis, manusia sempurna (insan kamil) adalah manusia

18 Otak manusia merupakan organ yang luar biasa. Otak khusus terdiri dari 100 milyar sel, yang masing-masing dari sel tersebut menghubungkan dan berkomunikasi sampai dengan 10.000 kolega-koleganya. Secara bersama-sama mereka membentuk jaringan yang luas dari satu quadrillion (1.000.000.0000.000.0000) hubungan yang menuntun bagaimana kita berbicara, makan, bernafas dan bergerak. James Watson menyatakan bahwa otak manusia merupakan hal yang paling kompleks yang belum ditemukan dalam dunia realitas. Lihat dalam Daniel H Pink, A Whole New Mind (Newyork: Riverhead Books, 2006), 26.

19 Secara etimologi, neurosains adalah ilmu neural (neural science) yang mempelajari sistem saraf, terutama mempelajari neuron atau sel saraf dengan pendekatan multidisipliner. Adapun secara terminologi, neurosains merupakan bidang ilmu yang mengkhususkan pada studi saintifik terhadap sistem saraf. Atas dasar ini, neuorosains juga disebut sebagai ilmu yang mempelajari otak dan seluruh fungsi-fungsi saraf belakang. Lihat dalam Suyadi, Teori Pembelajaran Anak Usia Dini "Dalam Kajian Neurosains" (Bandung: PT Remaja Rosdakarya, 2014), 7.

20 Suyadi, Teori Pembelajaran Anak Usia Dini "Dalam Kajian Neurosains" (Bandung: PT Remaja Rosdakarya, 2014), 5-6.

21 Eric Jensen, Brain Based Learning "The New Science of Teaching \& Training” (California: Corwin Press, 2007). Diterjemahkan oleh Narulita Yusron, Pembelajaran Berbasis Kemampuan Otak "Cara Baru dalam Pengajaran dan Pelatihan" (Yogyakarta: Pustaka Pelajar, 2008), 21.

22 Suyadi, Teori Pembelajaran Anak Usia Dini "Dalam Kajian Neurosains" (Bandung: PT Remaja Rosdakarya, 2014), 50. 
yang berkembang seluruh potensi atau kecerdasannya, baik potensi jasmani, ruhani, maupun akal (IQ, EQ, dan SQ). Seluruh potensi manusia bertumpu pada otaknya. Ilmu yang mempelajari otak adalah neurosains. Oleh karena itu, pendidikan dan neorosains dapat dipadukan dengan perekat psikologi. Lebih lanjut, Suyadi menjelaskan, bahwa secara teoritis terdapat kesamaan persepsi antara psikologi, pendidikan, dan neorosains sehingga ketiganya dapat dipadukan. Konsep manusia sempurna yang mempunyai unsur jasmani, ruhani, dan akal, sama dengan konsep psikologi tentang kognitif, afektif, dan psikomotorik. Demikian pula dengan neorosains yang mengandung unsur-unsur otak rasional (IQ), otak emosional (EQ), dan otak spiritual (SQ). Jika pemaduan pendidikan dan neurosains melalui perekat psikologi dilukiskan dalam skema, akan tampak sebagai berikut: ${ }^{23}$

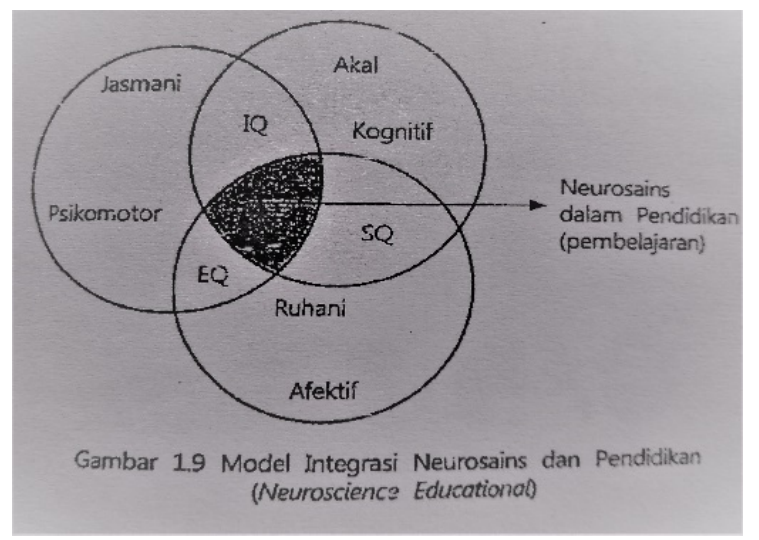

\section{Otak Sebagai Sebuah Pendekatan Dalam Pembelajaran}

Pendekatan ini berarti pembelajaran yang diselaraskan dengan cara otak yang didesain secara alamiah untuk belajar. Pendekatan berbasis kemampuan otak merupakan pendekatan yang multidisipliner yang dibangun di atas sebuah pertanyaan fundamental, apa saja yang baik bagi otak?. Pertanyaan ini berasal dari berbagai disiplin, seperti reaksi kimia, neurologi, psikologi, sosiologi, genetika, biologi, dan neorobiologi komputasi. Hal ini merupakan sebuah cara berpikir mengenai pembelajaran. Pendekatan ini bukan merupakan sebuah disiplin yang berdiri sendiri, dan juga bukan sebuah format yang ditentukan atau dogma. Pendekatan ini mendorong manusia untuk mempertimbangkan sifat alamiah otak dalam membuat keputusan. Dengan menggunakan pengetahuan tentang otak, dapat diciptakan putusan yang lebih baik, dan pembelajar akan dapat lebih banyak dijangkau, lebih sering, dengan tingkat kesalahan lebih kecil.. ${ }^{24}$

23 Ibid, . 50-51.

24 Eric Jensen, Brain Based Learning “The New Science of Teaching \& Training” (California: Corwin Press, 2007). Diterjemahkan oleh Narulita Yusron, Pembelajaran Berbasis Kemampuan Otak "Cara Baru dalam Pengajaran dan Pelatihan”, . 12. 


\section{Karakter Otak Kanan}

Anatomi otak manusia (neoroanatomi) membagi struktur otak berdasarkan belahan maupun posisi. ${ }^{25}$ Anatomi yang paling populer adalah belahan (hemisfer) otak kanan dan kiri. ${ }^{26}$ Seseorang yang dominan menggunakan (memfungsikan) otak kanannya lebih berpikir secara kreatif, lateral, seni, dan keindahan. Sedangkan orang yang menggunakan otak kirinya secara dominan berpikir secara kritis, logis, analitis, dan linier. ${ }^{27} \mathrm{Hal}$ ini senada dengan pendapat Daniel H Pink yang menyatakan bahwa otak manusia dibagi menjadi dua belahan. Belahan otak sebelah kiri adalah berurutan, logis, dan analitis. Sedangkan belahan otak kanan adalah non-linear, intuitif dan holistik. ${ }^{28}$ Sementara itu, Colin Rose dan Malcolm J. Nicholl berpendapat, bahwa otak kiri khusus diperuntukkan bagi aspek-aspek pembelajaran yang lazim disebut akademik (bahasa dan matematika), pemikiran logis, runtut, dan analitis. Sedangkan otak kanan terutama berhubungan dengan aktivitas-aktivitas kreatif yang menggunakan rima, irama, musik, kesan visual, warna, dan gambar. Otak kanan adalah pikiran "metaforis", mencari analogi dan pola. Ia juga berkaitan dengan kemampuan untuk berhubungan dengan jenis-jenis tertentu pemikiran konseptual "gagasan-gagasan” abstrak seperti cinta, keindahan, dan kesetiaan. ${ }^{29}$

Tabel: Karakteristik otak kiri dan kanan diadaptasi dari Torrence ${ }^{30}$

\begin{tabular}{|l|l|}
\hline Dominasi Otak Kiri & Dominasi Otak Kanan \\
\hline Intelektual & Intuitif \\
\hline Ingat nama & Ingat wajah \\
\hline Merespons intruksi verbal dan penjelasan & $\begin{array}{l}\text { Merespons intruksi yang diperagakan, } \\
\text { digambarkan, atau simbolis }\end{array}$ \\
\hline $\begin{array}{l}\text { Mencoba secara sistematis dan dengan } \\
\text { control }\end{array}$ & $\begin{array}{l}\text { Mencoba secara acak dan tidak terlalu } \\
\text { menahan diri }\end{array}$ \\
\hline Membuat penilaian objektif & Membuat penilaian subjektif \\
\hline
\end{tabular}

25 Suyadi, Teori Pembelajaran Anak Usia Dini “Dalam Kajian Neurosains”, . 42.

26 Sebutan otak kanan dan otak kiri pertama kali dipopulerkan oleh seorang guru besar dari Universitas California di era 1950-an, yakni Roger Sperry. Menurutnya, otak kanan memproses irama, kesadaran ruang, imajinasi, melamun, warna, dan dimensi. Sedangkan otak sebelah kiri memproses kata-kata, logika, angka, urutan, linearitas, analitis, dan daftar. Otak kiri mengukur hal-hal yang bersifat rasional, sedangkan otak kanan mengatur hal-hal yang bersifat ekstra rasional, termasuk berbagai seni dan keindahan. Lihat dalam Suyadi, Teori Pembelajaran Anak Usia Dini "Dalam Kajian Neurosains”, . 43.

27 Ibid

28 Daniel H Pink, A Whole New Mind (Newyork: Riverhead Books, 2006), 13.

29 Colin Rose dan Malcom J Nicholl, Accelarated Learning For The 21 st Century (London: Judy Piatkus, 1997), 54-55.

30 Douglas Brown, Prinsip Pembelajaran dan Pengajaran Bahasa (Jakarta: Dubes Amerika Serikat, 2008), 63. 


\begin{tabular}{|l|l|}
\hline Terencana dan terstruktur & Mengalir dan spontan \\
\hline Menyukai informasi tertentu dan pasti & Menyukai informasi tak pasti \\
\hline Pembaca analitis & Pembaca yang membuat sintesis \\
\hline $\begin{array}{l}\text { Mengandalkan bahasa dalam berpikir dan } \\
\text { mengingat }\end{array}$ & $\begin{array}{l}\text { Mengandalkan citra saat berpikir dan } \\
\text { mengingat }\end{array}$ \\
\hline Menyukai bicara dan menulis & Menyukai gambar dan objek bergerak \\
\hline Menyukai tes pilihan ganda & Menyukai pertanyaan terbuka \\
\hline Mengontrol perasaan & Lebih bebas dengan perasaan \\
\hline Tak pintar menafsiri bahasa tubuh & Pintar menafsiri bahasa tubuh \\
\hline Jarang menggunakan metafora & Sering menggunakan metafora \\
\hline Condong pemecahan masalah secara logis & $\begin{array}{l}\text { Codong pemecahan masalah secara } \\
\text { intuitif }\end{array}$ \\
\hline
\end{tabular}

Otak kanan juga berkaitan dengan emosi, oleh karenanya ia juga disebut dengan istilah EQ(EmotionalQuotient). ${ }^{31}$ Selanjutnya, hasil kerja otak emosional disebut dengan kecerdasan emosional. Goleman (1997) mendefinisikan kecerdasan emosional sebagai kemampuan untuk memotivasi diri, bertahan dalam menghadapi frustasi, mengatur suasana hati, menjaga agar beban stress tidak melumpuhkan kemampuan berfikir, berempati, dan berdoa. ${ }^{32}$ Dalam narasi yang lain, Howard Gardner menyatakan bahwa kecerdasan emosi terdiri dari dua kecakapan, yaitu: intrapersonal intelligence dan interpersonal intelligence. ${ }^{33}$ Lebih lanjut, Goleman menyatakan, bahwa paramater kecerdasan emosi dapat dilihat dari lima kategori utama, yaitu: 1) kesadaran diri: kesadaran emosi diri, penilaian pribadi, dan percaya diri, 2) Pengaturan diri: pengendalian diri, dapat dipercaya, waspada, adaptif, dan inovatif. 3) Motivasi: dorongan berprestasi, komitmen, inisiatif, optimis, 4) Empati: memahami orang lain, pelayanan, mengembangkan orang lain, mengatasi keragaman, kesadaran politis, 5)

31 Otak emosioanl berpusat di dalam sistem limbik. Sistem ini secara evolutif jauh lebih tua daripada bagian cortex cerebri. Artinya, pada awalnya bagian otak yang pertama muncul adalah sistem limbik. Fungsi sistem limbik adalah pengaturan emosi. Hal ini menunjukkan bahwa perkembangan otak manusia dimulai dengan pikiran emosional sebelum pikiran rasional berfungsi. Oleh karena itu, otak anak-anak pada dasarnya adalah otak emosional, bukan otak rasional. Atas dasar ini, pembelajaran yang efektif pada anak-anak adalah stimulasi emosionalitas, seperti memberikan rasa gembira, semangat, antusias, dan lain-lain. Lihat dalam Suyadi, Teori Pembelajaran Anak Usia Dini "Dalam Kajian Neurosains", . 119-120.

32 Ibid

33 Agus Nggermanto, Quantum Quotient “Kecerdasan Quantum” (Bandung: Nuansa, 2008), 98. 
Keterampilan sosial: pengaruh, komunikasi, kepemimpinan, katalisator perubahan, manajemen konflik, pengikat jaringan, kolaborasi dan korporasi, serta kerja tim. ${ }^{34}$

\section{Metode Penelitian}

Tulisan ini mencoba mendiskusikan permasalahan penting dan menarik, yaitu desain pengembangan pembelajaran bahasa Arab dengan pendekatan otak kanan. Pendekatan otak kanan diharapkan mampu responsif terhadap problem internal pembelajaran bahasa Arab yang miskin implikasi: miskin dalam nilai sosial, moral, dan spiritual. Tulisan ini mengandalkan sumber bibliografis berupa buku dan artikel yang berada di jurnal ilmiah yang berkaitan dengan pokok permasalahan. Pembacaan data pemikiran para akademisi dengan menggunakan pendekatan konstruktif kritis dan pemaknaan substansinya dengan analisis isi. ${ }^{35}$ Secara operasional penulis akan mengoptimalkan fungsi otak kanan dalam pembelajaran bahasa Arab dengan cara mengintegrasikan dan menginterkoneksikan konsep pembelajaran bahasa Arab dan diskursus otak kanan secara konstruktuf kritis sehingga menghasilkan desain pengembangan kurikulum pembelajaran bahasa Arab yang adaptable.

\section{Pembahasan}

\section{Pengembangan Kurikulum Bahasa Arab: Pendekatan Otak Kanan}

Kurikulum merupakan rancangan pendidikan yang memberi kesempatan untuk peserta didik mengembangkan potensi dirinya dalam suasana belajar yang menyenangkan dan sesuai dengan kemampuan dirinya untuk memiliki kualitas yang diinginkan di masyarakat dan bangsanya. Sedangkan menurut al-Bahjah, sebagaimana dikutip oleh Muhajir, tujuan pembelajaran bahasa Arab adalah untuk memberikan empat kemahiran berbahasa yang meliputi kemahiran mendengar (maharah al-Istima'), kemahiran berbicara (maharah al-Kalam), kemahiran membaca (maharah al-Qiro'ah), dan kemahiran menulis (maharah al-Kitabah) bagi peserta didik. Keterampilan berbahasa tersebut harus dijalankan berdasarkan kaidah-kaidah bahasa yang baik dan benar. ${ }^{36}$

Pada sub-bab ini, penulis berupaya untuk mendesaign kurikulum bahasa Arab berbasis pendekatan otak kanan dengan menggunakan strategi yang ditawarkan oleh Maksudin dan Qoim Nurani, yang meliputi: penentuan tujuan, penentuan pendekatan, penentuan metode pembelajaran, dan penentuan tekhnik pembelajaran bahasa Arab.

\section{Tujuan Pembelajaran Bahasa Arab}

34 Daniel Goleman, Kecerdasan Emosional (Jakarta: Gramedia Pustaka Utama, 1996), 58-59.

35 Content analysis adalah telaah sistematik untuk menganalisis isi pesan dan mengolah pesan atas catatan-catatan atau dokumen sebagai sumber data, sehingga diperoleh suatu hasil atau pemahaman terhadap berbagai isi pesan komunikasi yang disampaikan secara terbuka, obyektif dan sistematik. Lihat Dalam Sanapiah Faisal, Metodologi Penelitian Pendidikan (Surabaya: Usaha Nasional, 1982), 133.

36 Muhajir, Arah Baru Pengajaran Bahasa Arab, . 230. 
Tujuan menyeluruh pembelajaran bahasa Arab yang relevan dengan konteks Abad 21 dengan segala kompleksitas problematikanya menurut Fathul Mujib adalah mengintegrasikan dan menginterkoneksikan studi bahasa Arab dengan berbagai bidang studi. Mempelajari bahasa Arab untuk digunakan sebagai alat kaji di lapangan keilmuan dan praktis pergaulan kehidupan. Menumbuhkan dan membuat siswa mampu menyingkap permasalahan dengan keterampilan berbahasa, memperoleh latihan-latihan menggunakan bahasa untuk mengadakan hubungan sosial, termasuk mengaitkannya dengan al-Qur'an, mengetahui dan memahami teks-teks ajaran agama berdasarkan al-Qur'an dan kaitannya dengan permasalahan sosial kehidupan. ${ }^{37}$ Adapun dalam perspektif Muhajir, tujuan pembelajaran bahasa Arab dalam konteks kekinian adalah memberikan kecakapan, keterampilan berbahasa sesuai tingkatan atau levelnya dengan berbasis pada pengembangan nalar peserta didik. Lebih lanjut, Muhajir menjelaskan bahwa titik tekan pada kompetensi inti pembelajaran bahasa Arab adalah akumulasi kemampuan peserta didik dalam mengamati dan merespon setiap pengetahuan sehingga terinternalisasi menjadi sebuah kemahiran berbahasa. Upaya internalisasi setiap pengetahuan yang didapat tentunya berupa dialektika antara potensi nalar (otak) peserta didik, kondisi sosial-budaya, dan perangkat tekhnologi yang digunakan. Maka adanya ketiga dimensi tersebut dalam proses pembelajaran bahasa Arab merupakan sebuah keniscayaan. ${ }^{38}$

\section{Otak Kanan Sebagai Basis Pendekatan Pembelajaran Bahasa Arab}

Otak kanan sebagai basis pendekatan pembelajaran bahasa Arab bisa dinarasikan dengan cara berfikir aksiomatis tentang pembelajaran bahasa Arab dengan melihat potensi yang ada dalam otak kanan manusia. Potensi yang ada dalam otak kanan meliputi aktivitas-aktivitas kreatif yang menggunakan rima, irama, musik, kesan visual, warna, dan gambar. Otak kanan adalah pikiran "metaforis", mencari analogi dan pola. Ia juga berkaitan dengan kemampuan untuk berhubungan dengan jenis-jenis tertentu pemikiran konseptual "gagasan-gagasan" abstrak seperti cinta, keindahan, dan kesetiaan ${ }^{39}$ Sementara itu, Goleman berpendapat bahwa otak kanan mempunyai signifikansi dengan emosi, yang pada gilirannya akan menghasilkan kesadaran diri, pengaturan diri, motivasi, empati, dan kemampuan dalam bersosialisasi. ${ }^{40}$

\section{Metode Pembelajaran Bahasa Arab}

Metode adalah rencana menyeluruh yang berkenaan dengan penyajian pelajaran secara teratur, tidak ada satu bagian yang bertentangan dengan bagian yang lain dan semua itu didasarkan pada suatu pendekatan. ${ }^{41}$ Adapun metode pembelajaran bahasa Arab yang sesuai dengan pendekatan otak kanan adalah psychological method. Metode

37 Fathul Mujib, Rekonstruksi Pembelajaran Bahasa Arab, . 114.

38 Ibid, . 231-232.

39 Colin Rose dan Malcom J Nicholl, Accelarated Learning For The 21 st Century (London: Judy Piatkus, 1997), 54-55.

40 Daniel Goleman, Kecerdasan Emosional (Jakarta: Gramedia Pustaka Utama, 1996), 58-59.

41 Maksudin dan Qoim Nurani, Pengembangan Kurikulum Pembelajaran Bahasa Arab, . 141. 
ini dengan kaitannya dengan pembelajaran bahasa Arab menurut Ahmad Muhtadi Anshor sebagimana dikutip Ulin Nuha, berada pada cara memperhatikan keadaan jiwa para siswa, kesukaan hati mereka, apa yang disenangi mereka, atau suasana hati mereka pada umumnya. Bisa juga dikatakan metode psikologi adalah metode pembelajaran yang berdasarkan visualisasi mental dan asosiasi pikiran peserta didik. Sementara itu, Ulin Nuha berpendapat bahwa psychological method adalah sebuah metode yang dipakai dalam setiap pembelajaran, khususnya pembelajaran bahasa, dengan melihat kondisi perkembangan mental dan asosiasi pikiran para peserta didik. Dengan melihat perkembangan tersebut, seorang guru mampu menyesuaikan pelajarannya baik dari segi materi, lingkungan belajar, maupun media dengan kondisi siswa. Dengan demikian, prinsip utama dalam mempraktikkan metode ini adalah pelajaran bahasa Arab itu harus sesuai dengan kondisi jiwa si anak didik dan disenangi oleh mereka. Sehingga mereka merasa mudah menguasai pelajaran tersebut. ${ }^{42}$

\section{Teknik Pembelajaran Bahasa Arab}

Tekhnik merupakan suatu kreativitas guru untuk menerapkan metode pengajaran bahasa Arab tertentu di dalam kelas. Tekhnik bergantung pada guru, kemampuan pribadi dan komposisi kelas. Tekhnik sangat bergantung kepada imaginasi dan kreativitas guru bahasa Arab dalam meramu materi dan mengatasi berbagai problem yang dihadapi dalam kegiatan pengajaran dan pembelajaran bahasa Arab di kelas. ${ }^{43}$ Beberapa prinsip yang harus diperhatikan guru dalam menerapkan metode pembelajaran di dalam kelas yang menggunakan metode pembelajaran berbasis pendekatan otak kanan yaitu: 1) apakah aktivitas pembelajaran menarik minat siswa? Apakah itu relevan dengan hidup mereka?, 2) Apakah anda menghadirkan aktivitas dalam cara positif penuh semangat?, 3) Apakah siswa mengerti maksud aktifitas pembelajaran?, 4) Apakah siswa punya pilihan dalam memilih suatu aspek aktivitas dan atau menentukan bagaimana mereka memenuhi tujuan-tujuan aktivitas pembelajaran?, 5) Apakah aktifitas pembelajaran mendorong siswa untukmenemukan sendiri prinsip atau kaidah tertentu (bukan sekedar diberi tahu)?, 6) Apakah itu mendorong siswa, dalam suatu cara, mengembangkan atau menggunakan strategistrategi efektif pembelajaran dan komunikasi, 7) Apakah itu memberi kontribusi, setidak-tidaknya hingga tingkat tertentu, otonomi dan kebebasan tertinggi murid (dari anda)?, 8) Apakah itu memupuk negosiasi kooperatif dengan siswa lain dikelas? Apakah itu aktifitas yang interaktif?,9) Apakah aktivitas itu memberikan tantangan yang wajar?, 10) Apakah siswa menerima umpan baik yang cukup atas performa mereka (dari teman ataupun dari anda) $?^{44}$

42 Ulin Nuha, Metodologi Super Efektif Pembelajaran Bahasa Arab (Yogyakarta: Diva Press, 2012), 177-178.

43 Ibid, . 226.

44 Douglas Brown, Prinsip Pembelajaran dan Pengajaran Bahas, . 199. 


\section{E. Kesimpulan}

Otak kanan sebagai basis pendekatan pembelajaran bahasa Arab bisa dinarasikan dengan cara berfikir aksiomatis tentang pembelajaran bahasa Arab dengan melihat potensi yang ada dalam otak kanan manusia. Potensi yang ada dalam otak kanan meliputi aktivitas-aktivitas kreatif yang menggunakan rima, irama, musik, kesan visual, warna, dan gambar. Dalam pengembangan kurikulum bahasa Arab berbasis otak kanan, tujuan mempelajari bahasa Arab adalah untuk digunakan sebagai alat kaji di lapangan keilmuan dan praktis pergaulan kehidupan dengan cara yang menyenangkan, menumbuhkan dan membuat siswa mampu menyingkap permasalahan dengan keterampilan berbahasa, memperoleh latihan-latihan menggunakan bahasa untuk mengadakan hubungan sosial, termasuk mengaitkannya dengan al-Qur'an, mengetahui dan memahami teks-teks ajaran agama berdasarkan al-Qur'an dan kaitannya dengan permasalahan sosial kehidupan.

Adapun metode yang bisa digunakan dalam pembelajaran berbasis otak kanan ini salah satunya adalah psychological method. Metode ini pada prinsipnya sangat memberikan atensi kepada minat atau kesukaan siswa. Sementara itu, dalm tekhnik pembelajaran bahasa Arab berbasis pendekatan otak kanan, seorang guru harus memperhatikan prinsip-prinsip sebagai berikut: kegiatan pembelajaran harus dapat menarik siswa, pembelajaran harus mempunyai relevansi dengan siswa, aktifitas harus disajikan dengan penuh semangat dan antusias, siswa mempunyai pilihan dalam melakukan aktivitas, aktivitas pembelajaran harus mendorong siswa berpikir kritis, kreatif, dan holistik, harus mendorong siswa untuk kooperatif dan interaktif, dan harus ada umpan balik untuk siswa, baik dari guru ataupun teman kelasnya. 
El-Tsaqafah: Jurnal Jurusan PBA, Vol. 18, No.2, Desember 2019

\section{DAFTAR PUSTAKA}

Asrori, Mohammad. Pengembagan Kurikulum Bahasa Arab Di Pesantren. 2013. Malang: UIN-Maliki Press

Idi, Abdullah. Pengembangan Kurikulum "Teori dan Praktik". 2013. Jogjakarta: Arruz Media.

al-Fandi, Haryanto. Desain Pembelajaran Yang Demokratis dan Humanis. 2011. Jogjakarta: Arruz Media.

Nggermanto, Agus. Quantum Quotient "Kecerdasan Quantum". 2008. Bandung: Nuansa.

Ledoux, Joseph. The Emotional Brain "Penopang Misterius Bagi Kehidupan Emosional". 2011. Yogyakarta: Pustaka Baca

Brown, Douglas. Prinsip Pembelajaran dan Pengajaran Bahasa. 2008. Jakarta: Dubes Amerika Serikat.

Muhajir. Arah Baru Pengajaran Bahasa Arab "Filsafat Bahasa, Metode dan Pengembangan Kurikulum”. 2017.Yogyakarta: FITK UIN Sunan Kalijaga.

Faisal, Sanapiah. Metodologi Penelitian Pendidikan. 1982. Surabaya: Usaha Nasional

Maksudin dan Qoim Nurani. Pengembangan Kurikulum Pembelajaran Bahasa Arab "Teori dan Praktik”. 2018. Yogyakarta: Pascasarjana FITK UIN Sunan Kalijaga

H Pink, Daniel. A Whole New Mind. 2006. Newyork: Riverhead Books

Suyadi. Teori Pembelajaran Anak Usia Dini “Dalam Kajian Neurosains”. 2014. Bandung: PT Remaja Rosdakarya

Jensen, Eric. Brain Based Learning “The New Science of Teaching \& Training” . 2007. California: Corwin Press

Yusron, Narulita. Pembelajaran Berbasis Kemampuan Otak "Cara Baru dalam Pengajaran dan Pelatihan”. 2008. Yogyakarta: Pustaka Pelajar.

Rose, Colin dan Malcom J Nicholl. Accelarated Learning For The 21 st Century. 1997. London: Judy Piatkus

Goleman, Daniel. Kecerdasan Emosional. 1996.Jakarta: Gramedia Pustaka Utama

Mujib, Fathul. Rekonstruksi Pembelajaran Bahasa Arab "Dari Pendekatan Konvensional Ke Integratif Humanis”. 2010. Yogyakarta: Pedagogia

Nuha, Ulin. Metodologi Super Efektif Pembelajaran Bahasa Arab. 2012. Yogyakarta: Diva Press. 